\title{
Promoting and Harmful Effects of Steroid Hormones on Renal Stem/Progenitor Cell Development
}

\author{
Will W. Minuth*, Lucia Denk and Anne Glashauser \\ Molecular and Cellular Anatomy, University of Regensburg, University Street 31, D-93053 Regensburg, Germany
}

\begin{abstract}
In regenerative medicine much attention is given to stem/progenitor cells for a future therapy of acute and chronic renal failure. However, up to date sound cell biological knowledge about nephron renewal within the diseased kidney is lacking. Of special interest are steroid hormones occurring in the interstitial fluid. It is unknown, if they have promoting or hampering effects on the development of stem/progenitor cells.

To investigate the influence of steroid hormones on regenerating tubules a realistic culture system is of great importance. An advanced technique creates an artificial interstitium promoting renal stem/progenitor cells to develop tubules between layers of polyester fleece. During perfusion culture with chemically defined Iscove's Modified Dulbecco's Medium (IMDM) individual steroid hormones can be administered. After a culture period of 13 days the effect on tubule development is analyzed by histochemical methods.

Present experiments reveal that substances such as cholesterol and 17- $\alpha$-hydroxyprogesterone do not exhibit a visible effect on renal stem/progenitor cells. However, atypical aggregation of few SBA-labeled cells in form of islets is found after treatment with progesterone, pregnenolone, 11-deoxycorticosterone and dihydrotestosterone. Numerous SBA-labeled cells within extended clusters are observed after application of testosterone, $17-\beta$-estradiol, corticosterone and dexamethasone. In contrast, application of aldosterone exclusively leads to the formation of numerous intact tubules.

In consequence, it is shown that distinct steroid hormones induce a shift in development from intact tubules to atypical cell islets and clusters. Such harmful effects have to be considered, when stem/progenitor cells are exposed after implantation to the interstitial fluid within diseased renal parenchyma.
\end{abstract}

Keywords: Kidney; Regeneration; Steroid hormones; Aldosterone; Stem/Progenitor cells

\section{Introduction}

Clinical experiences show that regeneration of parenchyma is limited in patients with chronic or acute renal failure $[8,9]$. Due to that reason the question arises, which molecular processes hamper a diseased kidney to regenerate nephrons and to which degree such a process can be stimulated by the implantation of stem/ progenitor cells in combination with tissue engineering techniques and morphogenic drugs $[12,25]$. Consequently, actual research is focusing on hormones or growth factors supporting in combination within smart biomatrices the development of stem/progenitor cells into renal parenchyma $[1,28,38,39,48]$.

\section{Regeneration within a diseased environment}

Actual literature shows that a process of regeneration may occur via a local drug released stimulation of non-diseased parenchymal cells or an activation of organ specific stem/progenitor cells [56]. A different strategy follows the idea that stem/progenitor cells are applied to promote a process of regeneration after infusion, accidental or focal injection into a diseased kidney [7,45]. However, independently from the kind of activation regenerating cells are exposed to an irritating environment within the interstitium of a diseased kidney, where tubule cells undergo necrosis, apoptosis and detachment including denudation of the basal lamina [40]. At this unfriendly site stem/progenitor cells have first to terminate the process of degradation and turn it then into a process of regeneration. One of the presuppositions for regeneration is therefore the recreation of an optimal microenvironment within the interstitium suppressing inflammation but promoting cell proliferation and differentiation with subsequent spatial development of functional tubules.

\section{Formation of spatially organized tubules}

For steering therapeutically a process of regeneration exact information about kidney development is essential. In the meantime a multitude of papers is available dealing with renal organ anlage and the related primary reciprocal interactions between the ureter bud and the surrounding nephrogenic mesenchyme $[11,14]$. Thus, the primary step in kidney organogenesis and the formation of Comma-shaped bodies as first visible signs of nephron formation are intensively investigated. In contrast, up to date surprisingly little knowledge is available concerning the consecutive development of spatial tubule formation [21]. Except for phosphoinoside-3-kinase [27], mTOR signalling [22] and crumbs complex [46] the molecular mechanisms leading to nephron segmentation and functional maturation are unknown [20]. Also the formation of spatially structured tubules is up to date not understood [42]. The following developmental period comprises the sprouting of cells, the formation of a lumen and the elongation of the individual nephron segment. During proceeding development a highly specialized epithelium is integrated into a

*Corresponding author: Will W. Minuth, Molecular and Cellular Anatomy, University of Regensburg, University Street 31, D-93053 Regensburg, Germany, Tel: +49 (0)941 943 2876; Fax: +49 (0)941 943 2868; E-mail: will.minuth@vkl.uniregensburg.de

Received October 11, 2010; Accepted October 23, 2010; Published November 06, 2010

Citation: Minuth WW, Denk L, Glashauser A (2010) Promoting and Harmful Effects of Steroid Hormones on Renal Stem/Progenitor Cell Development. J Tissue Sc Eng 1:101. doi:10.4172/2157-7552.1000101

Copyright: (c) 2010 Minuth WW, et al. This is an open-access article distributed under the terms of the Creative Commons Attribution License, which permits unrestricted use, distribution, and reproduction in any medium, provided the original author and source are credited. 
tubule exhibiting exact geometrical dimensions such as length, inner and outer diameter $[24,30]$. It has to be elaborated if the formation of a renal tubule lumen arises by wrapping, budding, cavitation or hollowing [44]. Finally, during the last phase of nephron development unknown molecular mechanisms trigger microarchitectural features such as straight course, length, convolution or branching of a tubule resulting in a continuous expansion during organ growth.

\section{Aim of present experiments}

A challenge for future biomedicine is the repair of diseased renal parenchyma by implanted stem/progenitor cells [7,56]. Following this strategy stem/progenitor cells are transferred from a more or less comfortable in-vitro environment to the harmful atmosphere within a diseased kidney. Here the implanted cells are surrounded by the interstitial fluid, where they are exposed to a multitude of biologically active molecules including a mixture of steroid hormones. In consequence, to obtain first information about the influence of steroid hormones on the development of renal stem/progenitor cells, the present culture experiments were performed. The presented data provide new information that aldosterone is promoting the development of tubules, while a set of steroid hormones interferes this process leading to malformation in form of cell islets and clusters.

\section{Material and Methods}

\section{Source of stem/progenitor cells}

Due to the limited size of embryonic mouse or rat specimens, neonatal rabbit kidney was selected as a favorite model [32]. Even after birth the cortex of the kidney contained numerous stem cell niches within their original extracellular environment. Underneath the organ capsule two different kinds of stem/progenitor cell populations could be recognized [47]. Within the tip of the collecting duct ampulla epithelial stem/progenitor cells were found. Around each ampulla, numerous mesenchymal nephrogenic stem/progenitor cells were located.

\section{Isolation of tissue containing renal stem/progenitor cells}

Surprisingly, both epithelial and mesenchymal stem/progenitor cell populations did not stand in close contact to each other but were separated by a wide interstitial space [49]. Due to the lack of strong extracellular matrix fibers the embryonic tissue containing stem/progenitor cells was therefore easily accessible for isolation [32]. Stripping off the capsula fibrosa with fine forceps a thin layer of stem/progenitor cells adhered to the explant (Figure 1a). Applying this simple isolation method an embryonic tissue layer of up to $1 \mathrm{~cm}^{2}$ in square could be harvested. Up to date no other species is known for the isolation of renal stem/progenitor cells in such an amount necessarily needed for subsequent cell biological analysis.

\section{Creation of an artificial interstitium}

For following culture experiments the isolated layer containing stem/progenitor cells was placed between two punched out pieces of polyester fleece (I7, Walraf, Grevenbroich, Germany) (Figure 1b). This arrangement resulted in a sandwich set-up measuring $5 \mathrm{~mm}$ in diameter as earlier shown $[33,38,43]$. To prevent damage during culture the sandwich set-up was kept inside a perfusion culture container. For mounting a base ring of a Minusheet ${ }^{\circledR}$ tissue carrier (Minucells and Minutissue, Bad Abbach, Germany) with $13 \mathrm{~mm}$ inner diameter was used. First a polyester fleece measuring $13 \mathrm{~mm}$ in diameter was placed inside the tissue carrier. Then the sandwich set-up containing renal stem/progenitor cells was inserted. Finally,
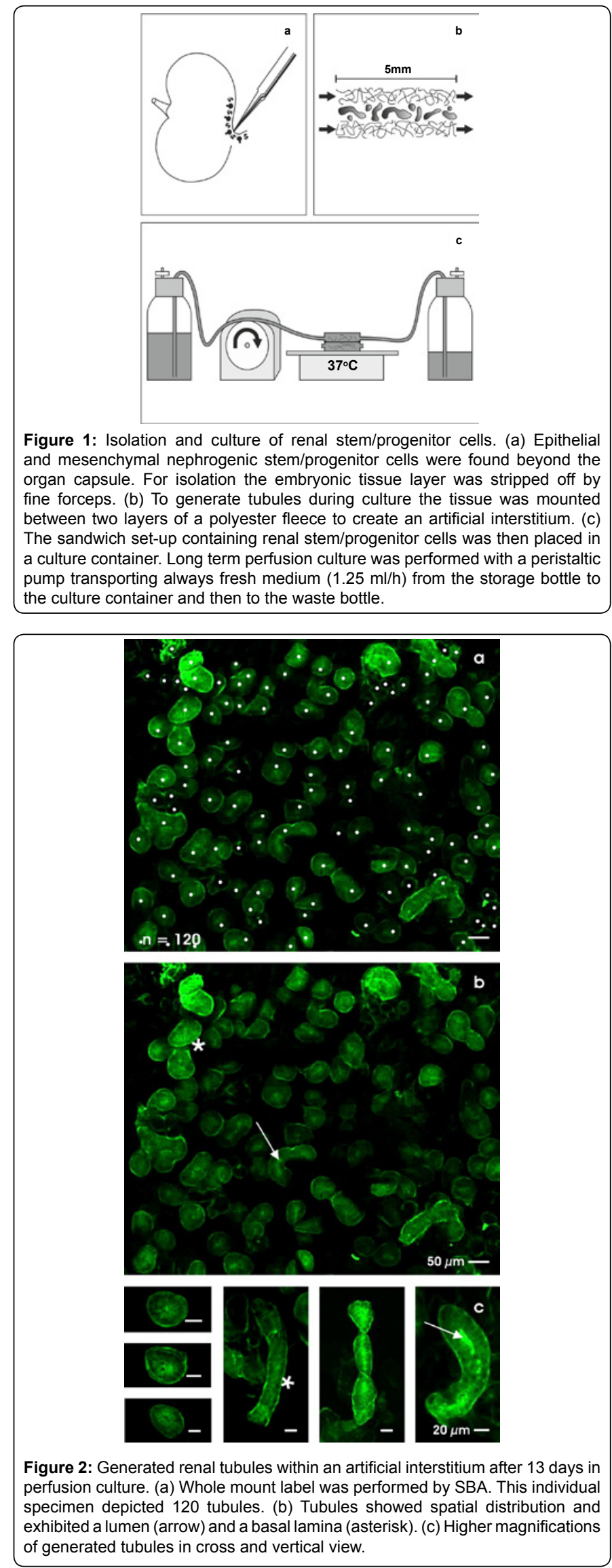
another fleece with $13 \mathrm{~mm}$ in diameter was placed on top. The tissue carrier was then transferred to a perfusion culture container with horizontal flow characteristics (Minucells and Minutissue). By closing the lid of the perfusion container the sandwich set-up was fixed in an exact position during culture.

\section{Perfusion culture}

For maintaining a constant temperature of $37^{\circ} \mathrm{C}$ the perfusion culture container was placed on a thermoplate (Medax-Nagel, Kiel, Germany) (Figure 1c). For a period of 13 days always fresh medium was continuously transported at a rate of $1.25 \mathrm{ml} / \mathrm{h}$ with an IPC N8 peristaltic pump (Ismatec, Wertheim, Germany). Applying this method medium was saturated up to $190 \mathrm{mmHg}$ oxygen during transport. This content of oxygen was reached by a long thin-walled silicone tube, which is highly gas-permeable. It guaranteed optimal diffusion of respiratory gas between culture medium and surrounding atmosphere. In this way it was possible to adjust the gas partial pressures within the medium under absolutely sterile conditions. By adding a defined amount of biological buffer such as HEPES (GIBCO/ Invitrogen, Karlsruhe, Germany) to the medium this method could be employed to control medium $\mathrm{pH}$ irrespectively if the system ran in a $\mathrm{CO}_{2}$-incubator or under atmospheric air.

\section{Culture medium}

For the generation of renal tubules chemically defined IMDM (Iscove's Modified Dulbecco's Medium) including Phenolred (GIBCO/Invitrogen) was used [26]. Infections were prevented by adding an antibiotic-antimycotic cocktail (1\%, GIBCO/Invitrogen). To induce tubulogenic development aldosterone $\left(1 \times 10^{-7} \mathrm{M}\right.$, Fluka, Taufkirchen, Germany) was administered. All other steroid hormones and metabolites were applied in the same concentration $\left(1 \times 10^{-7} \mathrm{M}\right)$. Cholesterol, pregnenolone, progesterone, 11-deoxycorticosterone, corticosterone, 17- $\alpha$-hydroxyprogesterone, dihydrotestosterone, testosterone, 17- $\beta$-estradiol and dexamethasone were obtained from Sigma-Aldrich, Taufkirchen, Germany. Data for 18-hydroxycorticosterone is lacking, since this substance was commercially not available.

\section{Histochemistry}

Whole mount specimens or cryosections of $20 \mu \mathrm{m}$ thickness were fixed in ice-cold ethanol. After washing with phosphate buffered saline (PBS) the specimens were blocked with PBS containing $1 \%$ bovine serum albumin (BSA) and 10\% horse serum for 30 minutes. For Soybean Agglutinin (SBA, Vector, Burlingame, USA) -labeling the samples were exposed to fluorescein-isothiocyanate (FITC) -conjugated lectin diluted 1:1000 in blocking solution for 45 minutes as earlier described [35]. For immunohistochemistry following primary antibodies were applied for $1 \mathrm{~h}$ in blocking solution: mab anti-collagen type III (III-53, Calbiochem, Schwalbach, Germany); mab anti-Na/K ATPase $\alpha 5$, mab anti-cytokeratin endo-A (TROMA-I) (Developmental Studies Hybridoma Bank, Department of Biological Sciences, University of Iowa City, Iowa, 52242, USA under contract NO1 - HD - 7- 3263 from the National Institute of Child Health and Human Development), mab anti-cingulin and mab anti-cytokeratin 19 (Progen Biotechnik, Heidelberg, Germany) and mab anti-laminin $\gamma 1$ (kindly provided by Prof. Dr. L. Sorokin, Lund, Sweden). The primary antibodies were applied for $1 \mathrm{~h}$ in blocking solution after washing with PBS. The specimens were then incubated for 45 minutes with donkey-anti-mouse-IgG-fluorescein-isothiocyanate, goat-anti-ratIgG-rhodamine or donkey-anti-guinea-pig-IgG-fluoresceinisothioIcyanate (Jackson Immunoresearch Laboratories, West Grove, USA) diluted 1:50 in PBS containing 1\% BSA. Following several washes with PBS the sections were embedded with Slow Fade Light Antifade Kit (Molecular Probes, Eugene, USA) and then analyzed using a LSM 710 confocal fluorescence microscope or an Axioskop 2 plus microscope (Zeiss, Oberkochen, Germany). Fluorescence images were taken with a digital camera at a standard exposure time of 1.3 seconds and thereafter processed with Corel DRAW 11 (Corel Corporation, Otawa, Canada). The counting of tubules was performed with a WCIF Image $\mathrm{J}$ morphometric program (Bethesda, Maryland, USA).

\section{Amount of cultured specimens}

A total of 138 embryonic renal explants was maintained in culture for the present study. All of the experiments were performed at least in triplicates. The data provided in the text are the mean of at least three independent experiments. Performed experiments are in accordance with the Animal Ethics Committee, University of Regensburg, Regensburg, Germany.

\section{Results}

Stem/progenitor cells are promising candidates for the regeneration of diseased renal parenchyma. However, after an implantation is made the stem/progenitor cells are exposed to the interstitial fluid containing a multitude of bioactive molecules including various steroid hormones. Since the influence of steroid hormones on renal stem/progenitor cells is not known, the following sets of culture experiments were performed.

\section{Tubulogenic effect of aldosterone}

After a culture period of 13 days the artificial interstitium was opened by tearing off the fleece layers. The spatial area for tissue development between the fleeces was $5 \mathrm{~mm}$ in diameter and up to $250 \mu \mathrm{m}$ in height. To recognize extend of tubule development, whole mount label was performed by fluorescent Soybean Agglutinin (SBA).

Spatial development: Interestingly, SBA-label on all cells was lacking and a disintegration of tissue is noticed, when perfusion culture of renal stem/progenitor cells was performed in chemically defined IMDM without steroid hormone administration (Figure 7a). In contrast, application of aldosterone $\left(1 \times 10^{-7} \mathrm{M}\right)$ led to development of numerous SBA-labeled tubules (Figure 2) [23].

To obtain information about the number of generated tubules a WCIF Image J program was used. Applying this technique at
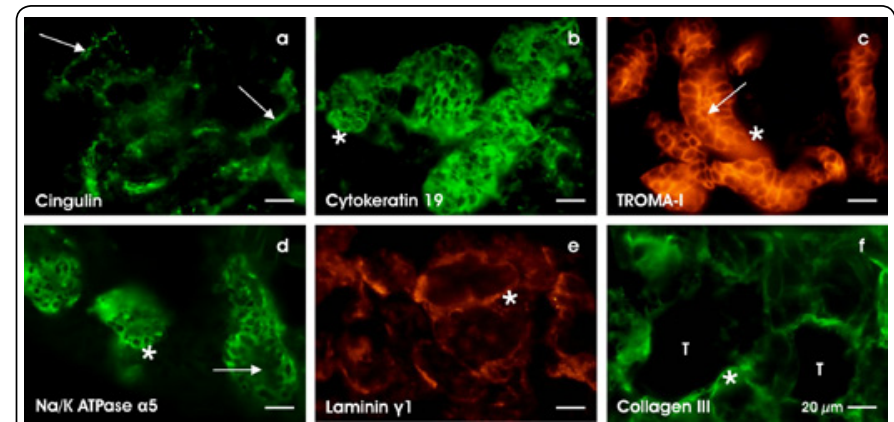

Figure 3: Immunohistochemical features of cryosectioned tubules generated for 13 days at the interface of an artificial interstitium. (a) Positive label for cingulin exhibited polarization of epithelial cells. (b) Strong label for cytokeratin 19 and (c) TROMA-I (cytokeratin endoA) depicted typical occurrence of intermediate sized filaments. (d) Intense reaction for Na/K-ATPase $\alpha 5$ was found at the basolateral aspect of epithelial cells. (e) Laminin $\mathrm{Y} 1$ was detected within the basal lamina of tubules. (f) Label for collagen III was present in the interstitial space between generated tubules. Tubule ( $\mathrm{T}$ ), lumen (arrow) and basal lamina (asterisk). 

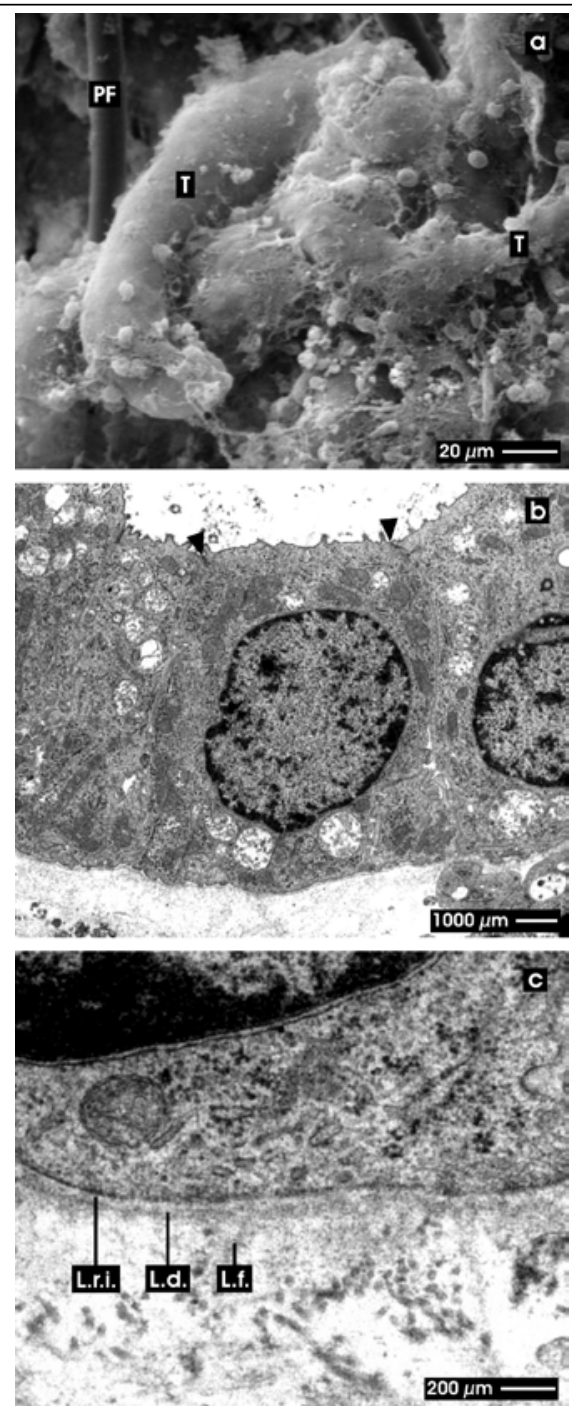

Figure 4: Electron microscopy on renal tubules generated for 13 days at the interface of an artificial interstitium. (a) Scanning electron microscopy demonstrated tubules $(T)$ in the vicinity of polyester fibers $(P F)$. On the surface of tubules single interstitial cells and synthesized fibers of extracellular matrix were observed. (b) Transmission electron microscopy depicted that generated tubules contain a polarized epithelium. Between the apical and lateral plasma membrane a junctional complex was developed (arrow head). (c) Higher magnification illuminated that at the basal side of epithelial cells a basal lamina was found consisting of a lamina rara interna (L.r.i.), a lamina densa (L.d.) and a lamina fibroreticularis (L.f.).

an individual example showed 120 tubules within a microscopic opening of $886 \times 729 \mu \mathrm{m}$ (Figure 2a). Fluorescence microscopy of SBA-labeled specimens further demonstrated that tubules were growing in a spatial arrangement. Part of them illustrated a straight forwarded growth, while others reveal a dichotomous branching or curling. If the tubules did not leave the optical plain, it was possible to follow their longitudinal growth over a distance between 300 and $400 \mu \mathrm{m}$. Labeled specimens further showed that generated tubules were exhibiting polarized cells, a visible lumen and a basal lamina (Figure 2b,c).

Features of differentiation: Performing immunohistochemistry more details about cellular differentiation within generated tubules were obtained. Label on cryosections showed reaction for cingulin at the tight junctional belt of tubule cells (Figure 3a). Within the cytoplasm cytokeratin 19 (Figure 3b) and cytokeratin endo-A (TROMA-I, Figure 3c) were detected. Bright reaction for Na/K-ATPase $\alpha 5$ could be recognized at the basolateral plasma membrane (Figure $3 d)$. Strong reaction for laminin $\gamma 1$ was visible at the basal lamina (Figure 3e). Most interestingly, intense label for collagen type III was found both in the basal lamina of generated tubules and in the surrounding interstitial space (Figure 3f).

Ultrastructural characteristics: An artificial interstitium replaced coating by extracellular matrix proteins. Since the surface was not sticked by proteins derived from a coating process, it was possible to analyze the basal aspect of generated tubules by scanning electron microscopy (SEM) [5]. The overall view demonstrated that generated tubules had only a loose contact to the fibers of the polyester fleece (Figure 4a). In part tubules developed in a parallel fashion, in other cases curling or dichotomous branching was observed. All of the tubules were covered by an intact basal lamina. On the outer surface of the basal lamina interstitial cells and bundles consisting of newly synthesized collagen and other extracellular matrix proteins were recognized.

Transmission electron microscopy (TEM) depicted that tubules were encountered in the neighbourhood of the polyester fleece fibers [37]. In the surrounding of a tubule synthesized extracellular matrix fibers and single interstitial cells were found. A crosssectioned view revealed that generated tubules contain a polarized epithelium (Figure $4 \mathrm{~b}$ ). The apical plasma membrane of isoprismatic cells bordered a lumen. The cells contained a large nucleus in the center. In the cytoplasm numerous lysosoms are found. Neighbouring epithelial cells were connected by a tight junctional belt consisting of a typical zonula occludens, zonula adhaerens and a desmosome. The basal lamina was consistently developed and exhibited a lamina rara interna, lamina densa and lamina fibroreticularis (Figure 4c).

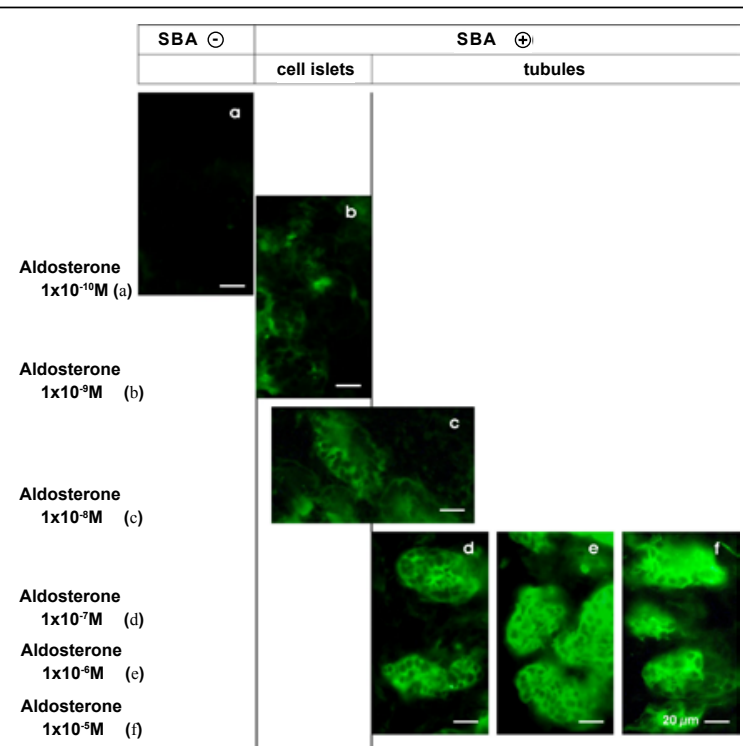

Figure 5: Tubulogenic effect of aldosterone after a 13 days culture period depended on applied hormone concentration. Histochemistry on cryosections showed that control without aldosterone administration lacked SBA-labeled cells and tubules. (a) A low dose of $1 \times 10^{-10} \mathrm{M}$ aldosterone did not show SBAlabel cells. (b) Administration of $1 \times 10^{-9} \mathrm{M}$ aldosterone produced SBA-labeled cells within islets. (c) Application of $1 \times 10^{-8} \mathrm{M}$ aldosterone stimulated SBAlabeled cells to form islets in combination with few tubules. Intense formation of SBA-labeled tubules was obtained by the use of (d) $1 \times 10^{-7} \mathrm{M}$ and (e) $1 \times 10^{-6}$ $\mathrm{M}$ aldosterone. (f) Application of $1 \times 10^{-5} \mathrm{M}$ aldosterone did not further improve the development. 


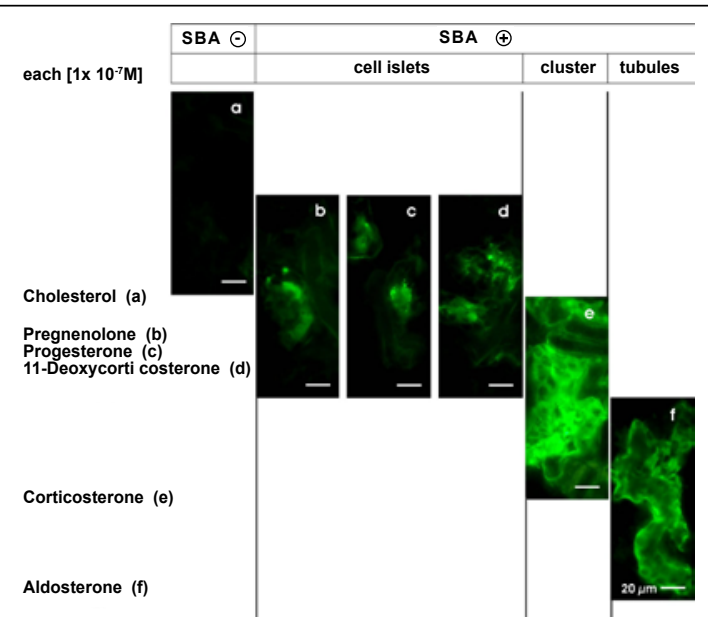

Figure 6: Precursors of the aldosterone synthesis did not stimulate developmen of SBA-labeled tubules. Histochemistry on cryosections showed that administration of (a) cholesterol lacked tubulogenic activity, while application of (b) pregnenolone, (c) progesterone and (d) 11-deoxycorticosterone produced SBA-labeled cell islets. (e) Administration of corticosterone induced numerous SBA-labeled cell clusters. (f) Use of aldosterone resulted in numerous SBAlabeled tubules exhibiting a distinct lumen (arrow) and a clearly recognizable basal lamina (asterisk) after 13 days of culture.

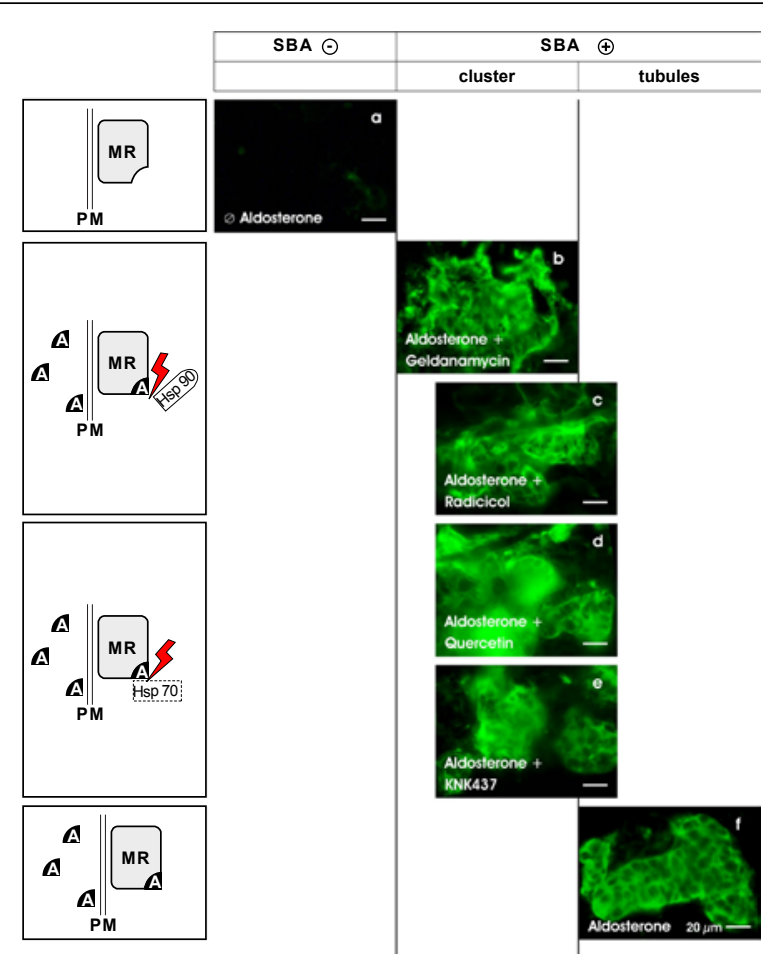

Figure 7: Generation of SBA-labeled tubules versus cell clustering by the interference of the tubulogenic signal between the mineralocorticoid receptor and heat shock proteins. (a) Histochemistry on cryosections demonstrated that renal stem/progenitor cells without hormone administration did not exhibit SBAlabel. (b) Formation of extended SBA-labeled cell clusters is observed after treatment with aldosterone $\left(1 \times 10^{-7} \mathrm{M}\right)$ in combination with geldanamycin $(3,6 \times$ $\left.10^{-6} \mathrm{M}\right)$. (c) Application of aldosterone $\left(1 \times 10^{-7} \mathrm{M}\right)$ in combination with radicicol $\left(2 \times 10^{-6} \mathrm{M}\right)$ led to cell clustering, while minimal formation of SBA-labeled tubules was oberserved. Both $(\mathrm{d})$ quercetin $\left(2 \times 10^{-4} \mathrm{M}\right)$ and $(\mathrm{e}) \mathrm{KNK} 437\left(1 \times 10^{-4} \mathrm{M}\right)$ in combination with aldosterone $\left(1 \times 10^{-7} \mathrm{M}\right)$ produced numerous SBA-labeled cells within extended clusters, while only single tubules were found. (f) Formation of intact tubules was observed after aldosterone $\left(1 \times 10^{-7} \mathrm{M}\right)$ administration, while occurrence of cell clusters was lacking.

\section{Exclusive action of aldosterone}

Earlier and present findings illustrated that aldosterone acts as a morphogenic factor [52]. To obtain more detailed information about the tubulogenic effect on renal stem/progenitor cells, aldosterone was applied in concentrations ranging from $1 \times 10^{-10} \mathrm{M}$ to $1 \times 10^{-5} \mathrm{M}$ (Figure 5). The experiments revealed that a low dose of $1 \times 10^{-10} \mathrm{M}$ aldosterone did not stimulate the development of SBA-labeled tubules (Figure 5a). A concentrations of $1 \times 10^{-9} \mathrm{M}$ (Figure 5b) of aldosterone resulted in cell islets, while administration of $1 \times 10^{-8} \mathrm{M}$ (Figure $5 \mathrm{c}$ ) stimulated growth of SBA-labeled cells forming islets and single tubules. Intact formation of tubules was obtained, when $1 \times 10^{-7} \mathrm{M}$ (Figure 5d) and $1 \times 10^{-6} \mathrm{M}$ (Figure 5e) aldosterone was present in the medium. Application of a higher dose of aldosterone $\left(1 \times 10^{-5} \mathrm{M}\right) \mathrm{did}$ not better stimulate the development of tubules (Figure $5 f$ ). Thus, the data showed that aldosterone stimulated development of tubules in a concentration-dependent manner reaching under perfusion culture in chemically defined medium a maximum at $1 \times 10^{-7} \mathrm{M}$.

From the adult kidney it is known that not only aldosterone but also the precursors of aldosterone synthesis show an affinity to the mineralocorticoid receptor (MR) influencing thereby physiological functions. For example, 11-deoxycorticosterone is as effective as aldosterone on MR [50], while corticosterone is 100 times less potent [18]. To investigate the tubulogenic effect of precursors of the aldosterone synthesis pathway the following experiments were performed (Figure 6).

Each precursor of aldosterone synthesis was applied in same concentration $\left(1 \times 10^{-7} \mathrm{M}\right)$. Thus, administration of cholesterol did not show SBA label (Figure 6a), while application of pregnenolone (Figure $6 \mathrm{~b}$ ), progesterone (Figure $6 \mathrm{c}$ ) and 11-deoxycorticosterone (Figure 6d) showed small SBA-labeled islets. Use of corticosterone did not stimulate development of tubules, instead numerous and extended SBA-labeled cell clusters were seen in close contact to polyester fibers (Figure 6e). Data for 18-hydroxycorticosterone are lacking, since this substance is not commercially available. For control, administration of aldosterone resulted in numerous SBA-positive tubules exhibiting a distinct lumen and a clearly recognizable basal lamina (Figure 6f). This series of experiments clearly demonstrated that precursors of aldosterone synthesis did not stimulate but disturb intact development of tubules.

\section{Involvement of MR}

To elaborate, if the tubulogenic effect of aldosterone was mediated via MR binding, aldosterone was applied in combination with antagonists such as spironolactone and canrenoate (no figure; see [37]). Application of spironolactone at a low dose $\left(1 \times 10^{-7} \mathrm{M}\right)$ in the presence of aldosterone did not affect the development of SBAlabeled tubules. However, use of increasing doses such as $1 \times 10^{-6}$ $\mathrm{M}$ and $1 \times 10^{-5} \mathrm{M}$ demonstrated unexpected effects. The number of structured tubules was reduced, while SBA-labeled cells aggregated to form extended SBA-labeled cell clusters. Presence of a high dose of spironolactone $\left(1 \times 10^{-4} \mathrm{M}\right)$ in aldosterone containing medium completely prevented the development of SBA-labeled tubules. For comparison, application of $1 \times 10^{-7} \mathrm{M}$ canrenoate in aldosteronecontaining medium did not affect the development of tubules. Administration of $1 \times 10^{-6} \mathrm{M}$ and $1 \times 10^{-5} \mathrm{M}$ canrenoate strongly reduced SBA-labeled tubules leading to cell cluster formation. Finally, the use of $1 \times 10^{-4} \mathrm{M}$ canrenoate resulted in a complete lack of SBAlabeled tubules. In so far both series of experiments elucidated that the tubulogenic effect of aldosterone could be antagonized by high doses of spironolactone and canrenoate. 


\section{Interfering the tubulogenic signal within the cytoplasm}

Earlier performed experiments demonstrated that MR is not randomly distributed within the cytoplasm of the target cell but stayed in close molecular contact with heat shock proteins (hsp) 90 and 70 $[3,41]$. To investigate this specific contact site renal stem/progenitor cells were cultured without aldosterone (Figure $7 \mathrm{a}$ ) or treated with aldosterone (Figure 7f) or in combination with substances (Figure 7be) that disrupt the molecular interactions between MR and hsp.

Geldanamycin specifically binds to hsp 90 thereby blocking the ATP-binding site due to its higher affinity compared to ATP. In this way it hinders the contact between hsp 90 and activated MR [55]. In consequence, renal stem/progenitor cells were cultured in IMDM containing geldanamycin $\left(3.6 \times 10^{-6} \mathrm{M}\right)$ and aldosterone $\left(1 \times 10^{-7} \mathrm{M}\right)$ for 13 days (Figure $7 \mathrm{~b}$ ). Structured tubules were not found in this set of experiments, instead numerous SBA-labeled cells were localized within extended clusters as earlier demonstrated [38].

Radicicol is a macrocyclic antifungal substance which binds in the same way as geldanamycin, thereby hindering ATP-dependent conformational changes of hsp 90. These changes are required for cytoplasmic interactions between target proteins such as MR [13]. When renal stem/progenitor cells were cultured with radicicol (1 $\left.\mathrm{x} 10^{-6} \mathrm{M}\right)$ in combination with aldosterone $\left(1 \times 10^{-7} \mathrm{M}\right)$ only single tubules, but numerous SBA-labeled cells within extended clusters were found (Figure 7c).

Quercetin inhibits hsp 70 expression by blocking heat shock factor 1 interfering thereby indirectly the contact with MR [31]. Treatment with quercetin $\left(2 \times 10^{-4} \mathrm{M}\right)$ and aldosterone $\left(1 \times 10^{-7} \mathrm{M}\right)$ produced numerous SBA-labeled cells within extended clusters, while formation of only single tubules was registered (Figure 7d).

KNK 437 is a benzylidene lactam molecule which inhibits heat shock factor activity resulting in a decreased expression of heat shock proteins so that it indirectly interferes with MR [31]. Culture experiments with KNK $437\left(1 \times 10^{-4} \mathrm{M}\right)$ in combination with aldosterone $\left(1 \times 10^{-7} \mathrm{M}\right)$ demonstrated that formation of only few tubules but numerous SBA-labeled cells within clusters become visible (Figure 7e).

\section{Distinct steroid hormones prevent tubulogenic development}

Actual experiments clearly demonstrated that both incomplete stimulation of MR by low concentrations of antagonists or disturbance of the contact site between MR and hsp prevented tubule formation leading to aggregation of SBA-labeled cells within cell islets or extended clusters. To obtain more insights in this phenomenon a set of further steroid hormones was tested (Figure 8).

One may assume that the tubulogenic development can be evoked by steroid hormones showing affinity to both the glucocorticoid receptor (GR) and MR. However, administration of 11-deoxycorticosterone $\left(1 \times 10^{-7} \mathrm{M}\right.$, Figure $\left.6 \mathrm{~d}\right)$ produced SBA-labeled cells within islets, while in corticosterone $\left(1 \times 10^{-7} \mathrm{M}\right.$, Figure 6e) treated specimens SBA-labeled cell within extended clusters was noticed. Also application of dexamethasone $\left(1 \times 10^{-7} \mathrm{M}\right)$ produced atypical aggregation of SBA-labeled cells in form of clusters, while development of tubules was not observed (Figure 8.f).

Beside glucocorticoids the influence of other steroid hormones on renal stem/progenitor cells was tested. In this last set of experiments the pattern of reactions could be asorted to four different categories. First of all, 17- $\alpha$-hydroxyprogesterone $\left(1 \times 10^{-7} \mathrm{M}\right)$ did not evoke
SBA-binding on cells and did not stimulate the formation of tubules (Figure 8a). However, application of dihydrotestosterone $\left(1 \times 10^{-7} \mathrm{M}\right)$ produced SBA-labeled cells within small islets (Figure $8 \mathrm{~b}$ ). In contrast, administration of testosterone $\left(1 \times 10^{-7} \mathrm{M}\right.$, Figure $\left.8 \mathrm{c}\right) 17$ - $\beta$-estradiol $\left(1 \times 10^{-7} \mathrm{M}\right.$, Figure $\left.8 \mathrm{~d}\right)$ and cortisol $\left(1 \times 10^{-7} \mathrm{M}\right.$, Figure $\left.8 \mathrm{e}\right)$ resulted in the formation of extended SBA-labeled cell clusters. In contrast, the exclusive use of aldosterone $\left(1 \times 10^{-7} \mathrm{M}\right)$ led to the development of intact SBA-labeled tubules, while formation of cell islets and clusters was prevented (Figure 8g).

\section{Discussion}

\section{Needing a three-dimensional in vitro model}

Intense research has to be performed to obtain the necessary cell biological information about regeneration of parenchyma within a chronically diseased kidney. However, due to the complex microarchitecture of the organ experiments on animals are difficult to perform. As an alternative advanced in vitro experiments can be made to obtain new insights in the action of hormones promoting or disturbing the process of regeneration.

It is obvious that in vitro experiments related to organo-typical regeneration cannot be performed in a conventional dish. For example, renal tubule segments were isolated and placed at the bottom of a culture dish [2,51]. Administration of a culture medium containing fetal bovine serum did not result in the elongation of the isolated tubule segment. In contrast, epithelial cells started to migrate, left the interior of the tubule and sprouted on the bottom of the culture dish or on the outer side of the basal lamina. Although the cells appeared vital, essential environmental parameters were missing so that the isolated tubule could not elongate.

\begin{tabular}{|c|c|c|c|c|}
\hline \multirow[b]{2}{*}{ each $\left[1 \times 10^{-7} \mathrm{M}\right]$} & SBA $\odot$ & \multicolumn{3}{|c|}{ SBA $\oplus$} \\
\hline & & cell islets & cluster & tubules \\
\hline \multicolumn{5}{|l|}{$\begin{array}{l}\text { 17- } \alpha \text {-Hydroxy- } \\
\text { progesterone (a) }\end{array}$} \\
\hline \multicolumn{5}{|c|}{ Dihydrotestosterone (b) } \\
\hline \multicolumn{5}{|l|}{ Testosterone (c) } \\
\hline \multicolumn{5}{|l|}{ 17- $\beta$-Estradiol (d) } \\
\hline \multicolumn{5}{|l|}{ Cortisol (e) } \\
\hline \multicolumn{5}{|c|}{ Dexamethasone (f) } \\
\hline Aldosterone (g) & & & & \\
\hline \multicolumn{5}{|c|}{$\begin{array}{l}\text { Figure 8: Effect of steroid hormones on renal stem/progenitor cells could be } \\
\text { divided into four categories: (a) Lack of SBA-label, (b) Formation of cell islets, } \\
\text { (c-f) extensive cell clusters and (g) tubule development with intensive SBA- } \\
\text { label. (a) 17- } \alpha \text {-hydroxyprogesterone did not reveal a positive effect on renal } \\
\text { stem/progenitor cell development. (b) Formation of SBA-labeled cell islets was } \\
\text { found after treatment with dihydrotestosterone. Extensive formation of SBA- } \\
\text { labeled cell clusters was detected after application of (c) testosterone, (d) } \\
17-\beta \text {-estradiol and (e) cortisol and (f) dexamethasone. (g) SBA-labeled tubule } \\
\text { formation was observed after aldosterone application. }\end{array}$} \\
\hline
\end{tabular}




\section{Improvement of extracellular environment}

To simulate an advanced environment for epithelia, renal cells were cultured within a filter insert to offer a substitute for the basal lamina $[6,19,51]$. In this kind of experiments it depended on the selected filter material, on pore size and on surface coating with extracellular matrix proteins, if a confluent growth in combination with an optimal polarization and functionality of the epithelial cells was obtained. Problematic was that the filter culture produced two-dimensional epithelial cell layers, while spatial development of tubules was not observed.

In advanced experiments MDCK cells were coated by extracellular matrix proteins to improve the spatial environment $[15,54]$. Using this type of protocol formation of cysts and tubules was observed after a few days of culture. However, for long term culture experiments the three-dimensional collagen coating is problematic. It does not support an optimal exchange of nutrition and respiratory gas leading to the formation of unstirred layers of fluid causing in turn a deleterious accumulation of metabolites.

\section{Providing an artificial interstitium}

When regeneration is simulated in culture, the environment has to meet the physiological needs of renal stem/progenitor cells so that spatial development of tubules is promoted. To substitute coating by extracellular matrix proteins, renal stem/progenitor cells can be mounted between layers of a polyester fleece (Figure 1b). This technique creates an artificial interstitium $[33,34,37,38]$. The interface between the fleece layers promotes the spatial development of tubules, while the space between the fleece fibers supports continuous exchange of nutrition and respiratory gas (Figure 1c, 2).

Keeping renal stem/progenitor cells within an artificial interstitium it was demonstrated that development of tubules was exclusively induced after application of aldosterone $\left(1 \times 10^{-7} \mathrm{M}\right)$ (Figure 2, 3, 4). The tubulogenic effect of aldosterone appeared to be specific, since the mineralocorticoid acted in a dose dependent manner (Figure 5). Higher concentrations of antagonists such as spironolactone and canrenoate completely abolished the tubulogenic effect of aldosterone (no figure, see para "Involvement of MR", [35].

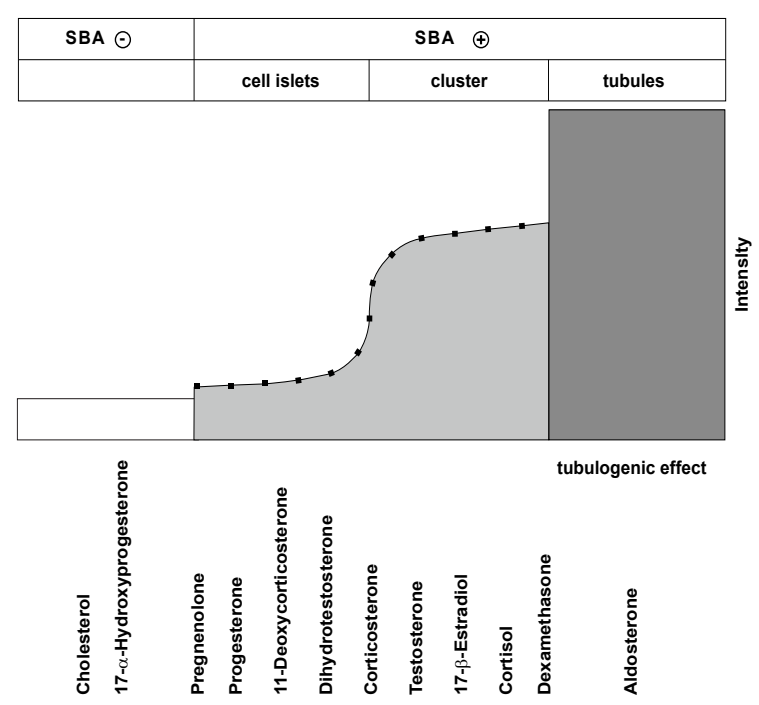

Figure 9: Effects of steroid hormones on the development of renal stem/ progenitor cells. Depending on the hormone administration cell islets, cluster and tubules arose.
However, lower concentrations of antagonists or inference between MR and hsp 90 and 70 (Figure 7) drastically reduced formation of tubules shifting the development to atypical cell islets and clusters.

\section{Switch between tubule, islet and cluster development}

Testing a set of different steroid hormones on renal stem/ progenitor cells revealed a developmental pattern, which could be assorted to four different categories (Figure 9). Cholesterol (Figure 6a) and 17- $\alpha$-hydroxyprogesterone (Figure 8a) did not exhibit tubulogenic action and did not show a visible SBA-label on cultured specimens. Atypical aggregation of SBA-labeled cells in form of small islets was found after treatment with pregnenolone (Figure $6 \mathrm{~b}$ ), progesterone (Figure 6c), 11-deoxycorticosterone (Figure 6d) and dihydrotestosterone (Figure $8 \mathrm{~b}$ ). In contrast, numerous SBA-labeled cells in form of extended clusters were observed after application of testosterone (Figure 8c), 17- $\beta$-estradiol (Figure 8d), cortisol (Figure $8 \mathrm{e}$ ) dexamethasone (Figure 8f) and corticosterone (Figure 6g). In contrast, treatment with aldosterone was leading to intact tubules (Figure 6f, 8g). In conclusion, the presented data point out that aldosterone exhibited a tubulogenic effect on renal stem/progenitor cells, while development was severely disturbed by a series of other tested steroid hormones (Figure 6, 8, 9).

Up to date no information is available about the molecular mechanisms switching between typical tubule development (Figure 2, 3, 4, 5d-f, 6f, 7f, 8g) and atypical formation of cell islets (Figure $6 b-d, 8 b$ ) or extensive clusters (Figure 6e, 7b-e, 8c-f). An explanation might be that unspecific binding of steroid hormones may destabilize the mineralocorticoid receptor [10] or that different steroid hormones may selectively modulate the mineralocorticoid function [4]. A further idea is that aldosterone is acting over a classical MR and a non-classical receptor [29]. Finally, proteins may interact with the cytosolic mineralocorticoid receptor depending on the presently binding ligand [53]. An alternative pathway for MR activation may be Rac1, a small GTP-binding protein [17].

In the present experiments it was further demonstrated that both undisturbed binding of aldosterone to MR and constant contact between MR to hsp 90 and 70 led to the development of intact tubules (Figure 7f). Interfering the contact site between MR and hsps by geldanamycin (Figure 7b), radicicol (Figure 7c), quercetin (Figure 7d) or KNK 437 (Figure 7e) resulted in atypical formation of SBA-labeled cell clusters. It appeared most likely that the contact between MR and related chaperons hsp 90 and 70 was the molecular site switching between specific tubule development (Figure $7 \mathrm{f}$ ) and atypical cell clustering (Figure 7b-e).

A challenge in future biomedicine is to implant stem/progenitor cells to initiate regeneration of diseased parenchyma within the kidney $[21,45,56]$. It appears most probable that stem/progenitor cells are not injected as a cell suspension but are administered within a nanostructure fleece material to concentrate at the site of damage and to facilitate the start of regeneration $[16,38,43]$. In this case it has to be considered that both the artificial interstitium and a variety of steroid hormones occurring in the interstitial fluid may influence the progress of regeneration. To the best of our knowledge, it is the first time that an interference of steroid hormones on development of stem/progenitor cells was demonstrated. The harmful influence of individual steroid hormones contained in the interstitial fluid of the kidney may be one of the reasons that implanted stem/progenitor cells show up to date a limited survival after implantation [7].

Experiments are in progress to compensate harmful effects 
Citation: Minuth WW, Denk L, Glashauser A (2010) Promoting and Harmful Effects of Steroid Hormones on Renal Stem/Progenitor Cell Development. $\mathrm{J}$ Tissue Sci Eng 1:101. doi:10.4172/2157-7552.1000101

Page 8 of 9

of steroid hormones and to elaborate the molecular mechanisms switching between solid development of SBA-labeled tubules and atypical formation of cell islets respectively clusters (Figure 9).

\section{Reference}

1. Aboushwareb T, Atala A (2008) Stem cells in urology. Nat Clin Pract Urol 5: 621-631.

2. Ash SR, Cuppage FE, Hoses ME, Selkurt EE (1975) Culture of isolated renal tubules: a method of assessing viability of normal and damaged cells. Kidney Int 7: 55-60

3. Bamberger CM, Wald M, Bamberger AM, Schulte HM (1997) Inhibition of mineralocorticoid and glucocorticoid receptor function by the heat shock protein 90-binding agent geldanamycin. Mol Cell Endocrinol 131: 233-240.

4. Baxter JD, Funder JW, Apriletti JW, Webb P (2004) Towards selectively modulating mineralocorticoid receptor function: lessons from other systems. Mol Cell Endocrinol 217: 151-165.

5. Blattmann A, Denk L, Strehl R, Castrop H, Minuth WW (2008) The formation of pores in the basal lamina of regenerated renal tubules. Biomaterials 29: 27492756

6. Brown CD, Sayer R, Windass AS, Haslam IS, De Broe ME, et al. (2008) Characterisation of human tubular cell monolayers as a model of proximal tubular xenobiotic handling. Toxicol Appl Pharmacol 233: 428-438.

7. Burst VR, Gillis M, Pütsch F, Herzog R, Fischer JH, et al. (2010) Poor cell survival limits the beneficial impact of mesenchymal stem cell transplantation on acute kidney injury. Nephron Exp Nephrol 114: e107-116.

8. Chhabra P, Brayman KL (2009) The use of stem cells in kidney disease. Curr Opin Organ Transplant 14: 72-78.

9. Coca SG, Yusuf B, Shlipak MG, Garg AX, Parikh CR (2009) Long-term risk of mortality and other adverse outcomes after acute kidney injury: a systematic review and meta-analysis. Am J Kidney Dis 53: 961-973.

10. Couette B, Lombes M, Baulieu EE, Rafestin-Oblin ME (1992) Aldosterone antagonists destabilize the mineralocorticosteroid receptor. Biochem $\mathrm{J} 282$ : 697-702.

11. Davies, Jamie A (2002) Morphogenesis of the metanephric kidney. Scientific World Journal 2: 1937-1950.

12. Ding F, Humes HD (2008) The bioartificial kidney and bioengineered membranes in acute kidney injury. Nephron Exp Nephrol 109 : e118-122.

13. Dokladny K, Wharton W, Lobb R, Ma TY, Moseley PL (2006) Induction of physiological thermotolerance in MDCK monolayers: contribution of heat shock protein 70. Cell Stress Chaperones 11: 268-275.

14. Dressler GR (2009) Advances in early kidney specification, development and patterning. Development 136: 3863-3874.

15. Eisen R, Walid S, Ratcliffe DR, Ojakian GK (2006) Regulation of epithelial tubule formation by Rho family GTPases. Am J Physiol Cell Physiol 290: C1297-1309.

16. Feng ZQ, Chu XH, Huang NP, Leach MK, Wang G, et al.(2010) Rat hepatocyte aggregate formation on discrete aligned nanofibers of type-I collagen-coated poly(L-lactic acid). Biomaterials 31: 3604-3612.

17. Fujita T (2010) Mineralocorticoid receptors, salt-sensitive hypertension, and metabolic syndrome. Hypertension 55: 813-818.

18. Gaeggeler HP, Gonzalez-Rodriguez E, Jaeger NF, Loffing-Cueni D, Norregaard $\mathrm{R}$, et al. (2005) Mineralocorticoid versus glucocorticoid receptor occupancy mediating aldosterone-stimulated sodium transport in a novel renal cell line. J Am Soc Nephrol 16: 878-891.

19. Genestie I, Morin JP, Guery C, Bode G, Lorenzon G (1997) Morphological and biochemical characterization of primary culture of rabbit proximal kidney tubule cells grown on collagen-IV coated Millicell-CM. In Vitro Cell Dev Biol Anim 33: 692-702.

20. Georgas K, Rumballe B, Valerius MT, Chiu HS, Thiagarajan RD, et al. (2009) Analysis of early nephron patterning reveals a role for distal RV proliferation in fusion to the ureteric tip via a cap mesenchyme-derived connecting segment. Dev Biol 332: 273-286.

21. Guo JK, Cantley LG (2010) Cellular maintenance and repair of the kidney. Annu Rev Physiol 72: 357-376.
22. Han HJ, Sigurdson WJ, Nickerson PA, Taub M (2004) Both mitogen activated protein kinase and the mammalian target of rapamycin modulate the development of functional renal proximal tubules in matrigel. J Cell Sci 117: 1821-33.

23. Heber S, Denk L, Hu K, Minuth WW (2007) Modulating the development of renal tubules growing in serum-free culture medium at an artificial interstitium. Tissue Eng 13: 281-292.

24. Hogan BL, Kolodziej PA (2002) Organogenesis: molecular mechanisms of tubulogenesis. Nat Rev Genet 3: 513-523.

25. Hopkins C, Li J, Rae F, Little MH (2009) Stem cell options for kidney disease. J Pathol 217: 265-281.

26. Hu K, Denk L, de Vries U, Minuth WW (2007) Chemically defined medium environment for the development of renal stem cells into tubules.. Biotechnol J 2: 992-995.

27. Ishibe S, Cantley LG (2008) Epithelial-mesenchymal-epithelial cycling in kidney repair. Curr Opin Nephrol Hypertens 17: 379-385.

28. Iwatani H, Imai E (2010) Kidney repair using stem cells: myth or reality as a therapeutic option? J Nephrol 23: 143-146.

29. Lösel RM, Wehling M (2008) Classic versus non-classic receptors for nongenomic mineralocorticoid responses: emerging evidence. Front Neuroendocrinol 29: 258-267.

30. Lubarsky B, Krasnow MA (2003) Tube morphogenesis: making and shaping biological tubes. Cell 112: 19-28.

31. Manwell LA, Heikkila JJ (2007) Examination of KNK437- and quercetinmediated inhibition of heat shock-induced heat shock protein gene expression in Xenopus laevis cultured cells. Comp Biochem Physiol A Mol Integr Physiol 148: $521-530$

32. Minuth WW (1987) Neonatal rabbit kidney cortex in culture as tool for the study of collecting duct formation and nephron differentiation. Differentiation 36:1222.

33. Minuth WW, Sorokin L, Schumacher K (2004)

34. Minuth WW, Strehl R, Schumacher K(2004) Tissue factory: conceptual design of a modular system for the in vitro generation of functional tissues. Tissue Eng 10: $285-294$

35. Minuth WW, Denk L, Hu K, Castrop H , Gomez-Sanchez C (2007) The tubulogenic effect of aldosterone is attributed to intact binding and intracellular response of the mineralocorticoid receptor. CEJB 2: 307-325.

36. Blattmann A, Denk L, StrehI R, Castrop H, Minuth WW (2008) The formation of pores in the basal lamina of regenerated renal tubules. Biomaterials 29: 27492756.

37. Minuth WW, Denk L, Meese C, Rachel R, Roessger A (2009) Ultrastructural insights in the interface between generated renal tubules and a polyester interstitium. Langmuir 25: 4621-4627.

38. Minuth WW, Denk L, Glashauser A (2010) Cell and drug delivery therapeutics for controlled renal parenchyma regeneration. Adv Drug Deliv Rev 62: 841-854.

39. Perin L, Giuliani S, Sedrakyan S, DA Sacco S, De Filippo RE (2008) Stem cell and regenerative science applications in the development of bioengineering of renal tissue. Pediatr Res 63: 467-471.

40. Pozdzik AA, Salmon IJ, Debelle FD, Decaestecker C, Van den Branden C, et al. (2008) Aristolochic acid induces proximal tubule apoptosis and epithelial to mesenchymal transformation. Kidney Int 73: 595-607.

41. Pratt WB, Galigniana MD, Harrell JM, DeFranco DB (2004) Role of hsp90 and the hsp90-binding immunophilins in signalling protein movement. Cell Signal 16: 857- 872 .

42. Raciti D, Reggiani L, Geffers L, Jiang Q, Bacchion F, et al. (2008) Organization of the pronephric kidney revealed by large-scale gene expression mapping Genome Biol 9: R84.

43. Roessger A, Denk L, Minuth WW (2009) Potential of stem/progenitor cell cultures within polyester fleeces to regenerate renal tubules. Biomaterials 30 3723-3732.

44. Rosines E, Sampogna RV, Johkura K, Vaughn DA, Choi Y, et al. (2007) Staged in vitro reconstitution and implantation of engineered rat kidney tissue. Proc Natl Acad Sci U S A 104: 20938-20943. 
Citation: Minuth WW, Denk L, Glashauser A (2010) Promoting and Harmful Effects of Steroid Hormones on Renal Stem/Progenitor Cell Development. $\mathrm{J}$ Tissue Sci Eng 1:101. doi:10.4172/2157-7552.1000101

Page 9 of 9

45. Roufosse C, Cook HT (2008) Stem cells and renal regeneration. Nephron Exp Nephrol 109: e39-45

46. Schlüter MA, Margolis B (2009) Apical lumen formation in renal epithelia. J Am Soc Nephrol 20: 1444-1452.

47. Schumacher K, Strehl R, De Vries U, Groene HJ, Minuth WW (2002) SBApositive fibers between the $C D$ ampulla, mesenchyme, and renal capsule. J Am Soc Nephrol 13: 2446-2453.

48. Steer DL, Nigam SK (2004) Developmental approaches to kidney tissue engineering. Am J Physiol Renal Physiol 286: F1-7.

49. Strehl R, Minuth WW (2001) Nephron induction--the epithelial mesenchymal interface revisited. Pediatr Nephrol 16: 38-40.

50. Sturm A, Bury N, Dengreville L, Fagart J, Flouriot G, et al. (2005) 11-deoxycorticosterone is a potent agonist of the rainbow trout (Oncorhynchus mykiss) mineralocorticoid receptor. Endocrinology 146: 47-55.
51. Sutterlin GG, Laverty G (1998) Characterization of a primary cell culture model of the avian renal proximal tubule. Am J Physiol 275: R220-226.

52. Thomas W, Dooley R, Harvey BJ (2010) Aldosterone as a renal growth factor Steroids 75: $550-554$.

53. Weber M, Wehling M, Lösel R (2008) Proteins interact with the cytosolic mineralocorticoid receptor depending on the ligand. Am J Physiol Heart Circ Physiol 295: H361-365.

54. Wei WC, Kopec AK, Tang MJ (2009) Requirement of focal adhesion kinase in branching tubulogenesis. J Biomed Sci 16: 5.

55. Xiao L, Lu X, Ruden DM (2006) Effectiveness of hsp90 inhibitors as anti-cancer drugs. Mini Rev Med Chem 6: 1137-1143.

56. Zubko R, Frishman W (2009) Stem cell therapy for the kidney? Am J Ther 16: 247-256. 